Check for updates

The BMJ

eloder@bmj.com

Cite this as: BMJ 2020;370:m2637 http://dx.doi.org/10.1136/bmj.m2637 Published: 02 July 2020

\section{Getting it right in the pandemic}

\section{Elizabeth Loder head of research}

The pandemic is far from over, but it's already obvious some countries have done better than others. Germany is one, with fewer infections and lower mortality from covid-19 than many of its European neighbours. Well timed lockdown measures and an extensive, community based system of testing and contact tracing have paid off, says Ralph Reintjes. ${ }^{1}$ There's still time to get this right in the UK, argue Peter Roderick and colleagues. ${ }^{2}$ They emphasise the need to "think local" and reintegrate testing and contact tracing into established regional systems. Meanwhile, the current centralised approach and reliance on commercially run tests mean that results are not reliably communicated to patients' GPs or those doing local contact tracing.

Another example of getting it right comes from China. In a research paper that warrants close scrutiny by hospital administrators everywhere, Min Liu and colleagues find that none of 420 healthcare workers deployed to a hospital in Wuhan were infected with the virus, despite caring for severely ill patients and performing aerosol generating procedures over 6-8 weeks. ${ }^{3}$ The workers wore surgical masks and N95 respirators as well as protective suits and gowns, goggles, gloves, and face shields. They also underwent extensive training in the proper use of personal protective equipment (PPE) and worked in pairs to properly don and doff outfits. Proper PPE saves lives ${ }^{4}$ and the lack of it for so many workers is one of the major scandals of the pandemic.

Sweden is everyone's favourite example of a country that got it wrong. Consensus is building that its laissez-faire herd immunity strategy has led to unnecessary levels of illness and death among vulnerable populations. ${ }^{5}$ But when it comes to getting things wrong Sweden has plenty of company. The US and the UK missed the just right "Goldilocks zone" of hospital capacity by building temporary hospitals that remained mostly empty. ${ }^{6}$ How did this happen? "Bad modelling based on insufficient data," says one expert. Still, even in hindsight, most criticism is muted: "The speed of the onset of the transmission of this disease ... was so quick that nobody should be surprised that errors were made," says Carl Heneghan. It's also the case that this strategy has been successful in China, where specialised covid hospitals helped offload mild cases from established facilities.

Policymakers and health systems everywhere have failed when it comes to involving patients and the public in decisions about managing the pandemic. Tessa Richards and Henry Scowcroft write that the pandemic has seen the "nothing about us without us" mantra left "hanging in the breeze." They say that involvement of people with "expertise rooted in lived experience" could have reduced some of the harm associated with pandemic responses among chronically ill people or those in lower socioeconomic groups. ${ }^{7}$

Getting it right is important when talking to patients and others about covid-19. This is tricky when policy and guidance are fast moving and changeable. Nathan Gray and Anthony Back have produced an engaging communication guide with messages and phrases that busy doctors can use in response to commonly asked questions. ${ }^{8}$ One suggested reply seems to sum up the whole pandemic so far: "Things are changing very fast. What we did a week ago is not what we are doing today."

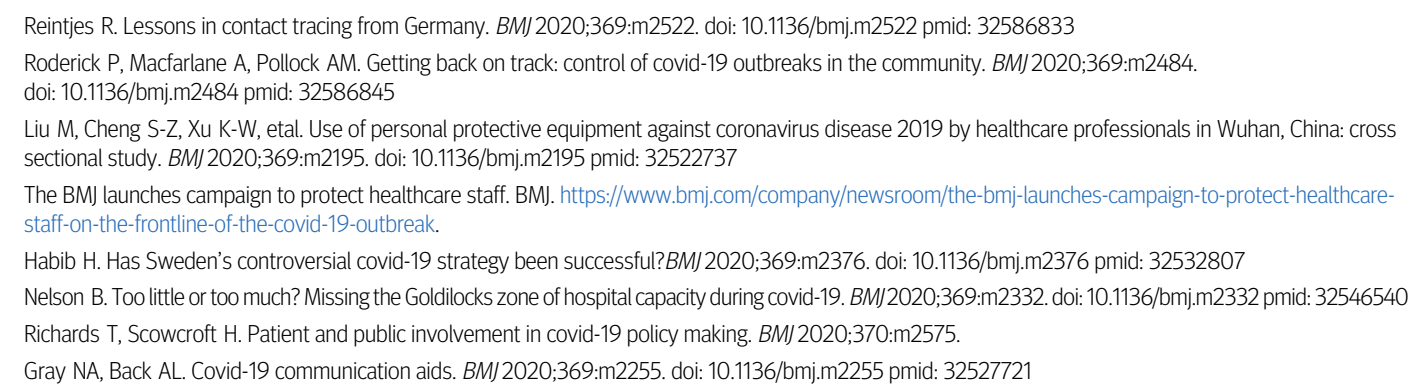

This article is made freely available for use in accordance with BMJ's website terms and conditions for the duration of the covid-19 pandemic or until otherwise determined by BMJ. You may use, download and print the article for any lawful, non-commercial purpose (including text and data mining) provided that all copyright notices and trade marks are retained. 